\title{
Medical-dental considerations in the care of children with facial cellulitis of odontogenic origin. A disease of interest for pediatricians and pediatric dentists
}

\author{
Claudia Giunta Crescente, Dentist ${ }^{a}$, Milagro Soto de Facchin, M.D. ${ }^{a}$ and \\ Andreína M. Acevedo Rodríguez, Dentist ${ }^{a}$
}

\begin{abstract}
An odontogenic infection is a polymicrobial, mixed infection (aerobic and anaerobic bacteria). It comprises various clinical conditions, whose importance varies depending on their frequency and potential severity. It is the most common type of oral infection and its treatment involves up to $10 \%$ of all antibiotic prescriptions. Facial cellulitis is a diffuse inflammation of soft tissue that is not confined or limited to a specific region and tends to spread. The objective of this review is to update the aspects considered in the care of children with facial cellulitis of odontogenic origin and the multidisciplinary management between dentists and pediatricians.

Key words: facial cellulitis of odontogenic origin, care, child.
\end{abstract}

http: / / dx.doi.org/10.5546/ aap.2018.eng.e548

To cite: Giunta Crescente C, Soto de Facchin M, Acevedo Rodríguez AM. Medical-dental considerations in the care of children with facial cellulitis of odontogenic origin. A disease of interest for pediatricians and pediatric dentists. Arch Argent Pediatr 2018;116(4):e548-e553.

\section{INTRODUCTION}

Most oral infections are usually of odontogenic origin and take place at a local, confined level, but they may sometimes spread by direct continuity and access deep tissue or, more rarely, spread via hematogenous or lymphatic routes and reach distant organs, which results in more severe processes. ${ }^{1}$

Cellulitis of odontogenic origin is an acute, deep, and diffuse inflammation of the subcutaneous tissue that spreads through the spaces between the tissue cells to several anatomic regions, tissue spaces, and throughout the aponeurotic plane because of the infection of one or several teeth or due to dental or supportive tissue-associated pathologies. $^{2}$

It has various clinical presentations, from a harmless, isolated process to a progressive, diffuse clinical condition that may cause complications. If cellulitis is detected at an early stage, it usually has a soft and smooth consistency with inflammatory signs, its edges are poorly-defined and, sometimes, the underlying epidermis is not raised up. In the advanced stage, the area is indurated. ${ }^{2}$

The intraoral examination includes assessing the level of mouth opening, which may be restricted by the presence of pain and trismus. The clinical characteristics include cleft effacement and tooth mobility or extrusion. ${ }^{2}$

The general symptoms of head and neck infections vary. Sepsis presents with apathy, weakness, discomfort, fever spikes, sweating, thready pulse, leukocytosis and, sometimes, marked secondary anemia. Muscle spasm or immobilization of adjacent muscles causes trismus, torticollis, and stiffness. Neural involvement causes pain in the affected sensory nerve and motor nerve paralysis. Dysphagia, dysphonia, and aphonia may also occur, depending on the site of infection. ${ }^{1}$

The treatment of facial cellulitis of odontogenic origin in children depends on the patient's general status and the course of the clinical condition. The main objective is to control and eliminate the causative agent, which, in some cases, requires the specialized care of a pediatrician and hospital management. ${ }^{3}$ 


\section{ETIOLOGY}

The etiopathogenesis of facial cellulitis of odontogenic origin is an illness in the dental and periodontal structures. The main cause is a dental cavity that was not treated in time, which compromises the pulp, in general, pulp necrosis of the affected dental structure. ${ }^{2}$ It is conditioned by two factors: the great virulence of the causative agent and the immunocompromised status of the patient. $^{3}$

Odontogenic infections are frequent in the pediatric population, especially among children younger than 6 years and, most commonly, boys. In this regard, the prevalence of facial cellulitis has increased in the past decades. Establishing the primary infection site and the causative agents may be challenging due to the proximity of the intimal layer, teeth, salivary glands, sinuses, and ear canal. The microbial flora and the site of origin of the infection may vary and should be determined so that the most effective treatment regimen may be instituted. Facial cellulitis of odontogenic origin in children is similar to that in adults; however, pediatric patients deserve special considerations due to their acute course resulting from the easy dissemination to deep spaces. ${ }^{4}$

The local immune system of the oral mucosa plays a key role in the body's defense mechanisms. A large number of immunocompetent mononuclear cells have been found on the surface of oral mucosa. B and plasma cells, with the help of some T cells, are responsible for immunoglobulin synthesis at a local level: IgA, IgE, and small amounts of IgG and $\operatorname{IgM}$, regardless of the systemic immune system. These immunoglobulins are part of the first line of defense of the oral mucosa. ${ }^{5}$

In the case of microbial aggression against the tissue, non-specific mechanisms react by causing an inflammatory response. These include the release of mediators, vascular changes (vasodilation and vasopermeability), cell exudate, and leukocyte activation, mainly polymorphs. If such inflammatory reaction continues, mononuclear cells (monocytes and lymphocytes) develop and granulation tissue forms subsequently.,

In the inflammatory process, the condition may be complicated depending on the relevance of the microbial aggression and the body's defense ability. This may cause a systemic inflammatory response which, sometimes, leads to septic shock, multiple organ failure, and finally, death. ${ }^{6}$

\section{Microorganisms involved in}

\section{facial cellulitis of odontogenic origin}

If conditions are favorable (certain metabolic circumstances, mucosal injury, immunocompromise, microbial ecosystem imbalance, etc.), oral commensal microorganisms may turn into opportunistic pathogens. Therefore, the bacteria isolated in an odontogenic infection are the same that make up the microbiota. ${ }^{6}$

Oral infections may be bacterial, fungal, or viral. Odontogenic infections tend to be mixed (aerobic and anaerobic bacteria), although anaerobic microorganisms prevail. . $^{70}$

The most common microorganisms involved are Streptococcus-like facultative Gram-positive aerobic organisms and strict Gram-negative organisms such as Prevotella, Porphyromonas and Fusobacterium. ${ }^{11}$

The most common bacterial agents involved in odontogenic infections are Streptococcus mutans $(24.5 \%)$, Porphyromonas gingivalis $(23.6 \%)$, and Porphyromonas endodontalis (18.2\%). Depending on virulence factors, bacterial metabolism, and the patient's nutritional requirements, the most relevant causative agents are Streptococcus salivarius $(10.1 \%)$ and Streptococcus sanguis $(8.2 \%) .12,13$

On their side, Leitao, Pedemonte, and Basili, in their study on microbial action in children and adults, found differences in orofacial infections caused by pulp necrosis in both groups. They reported that aerobic infections were significantly more common in children (20\%) compared to adults $(10 \%)$, that anaerobic infections were significantly more frequent in adults $(40 \%)$ and nonexistent in children $(0 \%)$, and that mixed infections predominated in both groups (children: 75\% ; adults: $45 \%) .{ }^{12-14}$

Another microorganism involved in facial cellulitis of odontogenic origin in children is Streptococcus pyogenes, sometimes in association with other microorganisms present in the oral bacterial flora. ${ }^{15}$

The following factors contribute to infection dissemination:

\section{General factors}

- Reduced immunity: bacterial growth and dissemination are faster in the case of systemically compromised patients (e.g., those with uncontrolled diabetes), whose resistance is reduced, even if the number of microorganisms is not high and their virulence, insignificant. ${ }^{16}$ 
- Virulence: it depends on the microorganism's qualities, which favor invasiveness through the production of lytic enzymes, endotoxins, and exotoxins. ${ }^{16}$

- Number of bacteria: it is important because, in the primary source of infection, it affects the size of the infection; at the same time, it increases the ability to defeat the host's defense mechanisms and the level of toxic substances. ${ }^{16-18}$

\section{Local factors}

- The alveolar bone is the primary local barrier. The infection spreads radially and subsequently relates to the periosteum, which is more developed in the mandible than in the maxilla. In most cases, the infection spreads to the underlying soft tissue; the anatomical disposition of muscles and aponeuroses determines the next infection site. ${ }^{16}$

\section{Potential complications if facial cellulitis of odontogenic origin is not treated adequately}

Most odontogenic infections are usually managed adequately with few complications; however, if they disseminate, they may cause severe complications, including death. ${ }^{8}$

These include odontogenic sinusitis, periorbital infections, cavernous sinus thrombosis, bacterial endocarditis, Ludwig's angina, cervicofacial necrotizing fasciitis, brain abscess, meningitis, mediastinitis, septicemia, gangrenous encephalitis, gangrenous pneumonia, thrombophlebitis of the jugular veins, edema of glottis. ${ }^{17,18}$

The complications of this pathology will directly depend on the patient's general status and immune system, and the presence or absence of a systemic disease, which may worsen the process. Facial cellulitis of odontogenic origin in children is characterized by the speed of the septic process induced by the extent of the medullary spaces, which is life-threatening. It may cause seizures and high fever with brain damage. The child may have dehydration depending on his/ her own characteristics. In addition, skeletal growth centers may be affected. ${ }^{18}$

Patients may be referred to a hospital for specialized medical-surgical care if any of the following criteria is observed: rapidly progressing cellulitis, dyspnea, dysphagia, dissemination to deep spaces, fever higher than $38^{\circ} \mathrm{C}$, severe trismus of the temporomandibular joint (TMJ), patients who do not collaborate or are unable to follow an outpatient treatment on their own, initial treatment failure, severe general status compromise, and immunocompromised patients. ${ }^{12,19}$

Some patients have been reported to have diffuse odontogenic infections, which leads to sepsis, including the mediastinum, and liver disease in those with immunocompromising conditions. ${ }^{20,21}$

In a pediatric patient, the infection may not be confined to the local tissues and spread through the less resistant route, therefore affecting the superficial maxillofacial spaces in the first place and even compromising deep anatomical spaces. For this reason, it is necessary for health care providers and dentists to know how to manage odontogenic infections in children so as to avoid complications, if possible. ${ }^{22}$

Some of the complications account for a higher life threatening risk for the patient, such as cavernous sinus thrombosis, which may be caused by an infectious or non-infectious process. ${ }^{22}$

In severe infections of the mediastinum, only a timely diagnosis and treatment may reduce the high mortality rate of this disease. Necrotizing mediastinitis is mostly caused by oropharyngeal infections, especially those of odontogenic origin. ${ }^{23-26}$

Another severe complication is Streptococcus pyogenes necrotizing fascitis, which implies a surgical emergency with a higher mortality rate among children due to its rapid progression to shock and multiple organ failure. The challenge posed by this disease is making an early diagnosis, since it is usually confused with a mild soft tissue infection. ${ }^{27}$

Last, but not least, other severe complications include periorbital infections, which may result from an infection of the maxilla that spreads directly, although the hematogenous route is also a possibility. The orbit is a partially closed anatomical structure with thin walls, no deep lymphatic system, and valveless veins. An orbital infection that is misdiagnosed and inadequately treated may lead to cavernous sinus thrombosis and spread and cause thrombophlebitis of adjacent veins, leading to eyeball tenderness, hyperthermia, eye pain, ptosis, etc. ${ }^{28-30}$

\section{Multidisciplinary management of facial cellulitis of odontogenic origin in children}

The treatment of facial cellulitis of odontogenic origin in children depends on the patient's general 
status and the course of the clinical condition. To treat and resolve the infection, it is necessary to take the patient's history, make an adequate diagnosis, recognize the causative agent, and, in this case, identify the tooth that is considered the main source of infection. The corresponding diagnostic methods should be used, including periapical and panoramic X-rays, an extraoral and intraoral clinical examination of the patient, assessment of the patient's general condition and, in some cases, a computed tomography and soft tissue ultrasound. ${ }^{1,31}$

Not all odontogenic infections require antibiotic therapy; it depends on the infection characteristics. In general, if a child has odontogenic cellulitis, most parents are unaware of its etiology, and for this reason, the child is referred to a health care center for the corresponding diagnostic tests to look for the cause of infection. ${ }^{11}$

Treatment is based on two essential principles: elimination of the underlying cause and local draining or debridement together with the use of oral or parenteral antibiotics. ${ }^{12}$

If a local infection remains untreated, it may spread to the upper or lower regions of the face. ${ }^{32-34}$ Children have special characteristics that increase their chances of this occurring. Their general anatomical and physiological characteristics are highly variable due to the wide age range of patients seen in pediatric dentistry. ${ }^{35}$

From a local perspective, the maxillae of children also display different anatomical characteristics. The presence of tooth germs, the larger amount of cancellous bone with wider medullary spaces, and the presence of bone growth centers make infections spread more rapidly in children than in adults. The pediatric dentist should consider the patient's clinical course and pay attention to the warning signs that may indicate the need for hospitalization. ${ }^{36}$

Hospital management is indicated for patients who have more than two aponeurotic spaces affected, those who cannot tolerate oral therapy, and those whose infection cannot be managed in the outpatient clinic. . $^{1,35}$

The following are the hospitalization criteria for a child or adolescent with odontogenic cellulitis:

- General status compromise and/or immunocompromised patient, e.g., a subject with diabetes, malnutrition, human immunodeficiency virus (HIV), etc.

- Rapidly progressing cellulitis.
- Time elapsed, in general, more than 24 hours.

- Cellulitis spreading to deep facial spaces.

- Upper airway involvement (parapharyngeal, pretracheal, retropharyngeal spaces).

- Fever higher than $38^{\circ} \mathrm{C}$, dyspnea and/or dysphagia and/or severe trismus restricting mouth opening to less than $10 \mathrm{~mm}$.

- A patient or family who do not collaborate or are unable to follow the prescribed outpatient treatment.

- Initial treatment failure.

If during the dental examination, it is determined that the patient meets the criteria for hospitalization, a pediatrician should be consulted for an assessment, to stabilize the patient and reinstate medical and nutritional support, administer fluids and electrolytes, and start antibiotic therapy and analgesia depending on the affected tissue. ${ }^{36}$

From a dental perspective, priority should be given to local treatment in the case of odontogenic infections that affect either the primary teeth of children or the permanent teeth of adolescents. This consists in opening the affected tooth for dental drainage, with or without root canal cleaning, to allow pus content, if any, to drain. If no local treatment is implemented and only antibiotics are given, the infection virulence will be reduced but it may flare-up once the medication is discontinued. ${ }^{37}$

Once the acute odontogenic infection is resolved, definite treatment should be decided: either keep the tooth with a non-vital pulpectomy plus definite restoration or dental extraction; this will depend on X-ray findings. ${ }^{37}$

Historically, beta-lactam antibiotics have been the first line treatment for odontogenic infections. Crystalline penicillin G (parenteral) and penicillin $\mathrm{V}$ (oral) are highly effective because most bacteria are sensitive to them; however, Prevotella, Bacteroides, and other microorganisms produce penicillin-resistant enzymes. In this setting, inhibitor-associated aminopenicillins (amoxicillin/clavulanic acid and ampicillin/ sulbactam) are the first therapeutic option in most dental infections and related complications, as long as the patient does not have penicillin hypersensitivity. ${ }^{3}$

There is another classification for the hospitalization of children and adolescents with odontogenic infections:

1. Mild odontogenic infections: oral amoxicillin + clavulanic acid. ${ }^{38}$

2. Cellulitis and parulides: oral amoxicillin + 
clavulanic acid (if oral treatment shows no response or the infection progresses rapidly, intravenous clindamycin is an alternative for treatment). ${ }^{38}$

3. Severe facial cellulitis: intravenous amoxicillin + clavulanic acid at $100 \mathrm{mg} / \mathrm{kg} /$ day.

In some countries, clindamycin is not available as oral solution, which is a problem in the setting of pediatrics and pediatric dentistry; for this reason, parenteral clindamycin could be administered to patients with penicillin hypersensitivity. 37,38

\section{CONCLUSIONS}

An early and adequate diagnosis of facial infections of odontogenic origin by the primary care pediatrician, an appropriate antibiotic use, and dental treatment are key for the rapid resolution of this condition. Essentially, patients with rapidly progressing facial cellulitis of odontogenic origin, trismus, general status compromise or oral antibiotic therapy failure should be referred for hospitalization. A timely diagnosis and hospital management may prevent severe complications.

It is imperative to have a pediatric dentist available at the hospital due to the high prevalence of this type of conditions and the complications that may develop if not managed adequately.

Further studies on this topic are required and it is necessary to insist on oral hygiene and periodic dental exams, which are essential to prevent and treat dental cavities and periodontal disease and avoid their progression.

\section{REFERENCES}

1. Batista Sánchez T, Martínez Chacón M, Rojas Escobar R, et al. Celulitis facial odontógena en pacientes del Hospital Lenin de Holguín. CCM 2017; 21(2):34-6.

2. Grandas Ramírez AL, Velásquez Cuchia S. Prevalencia de celulitis odontogénica en pacientes de 0 a 18 años que asistieron a la Fundación HOMI-Hospital de la Misericordia de Bogotá entre Febrero de 2009 a Febrero de 2011. Acta Odontol Col 2012; 2(1):71-85.

3. Zambrano G, Rondón R, Guerra ME. Diente más afectado por la celulitis facial de origen odontogénico en niños venezolanos. Rev Odontopedatr Latinoam 2016; 6(2):81-9.

4. Kara A, Ozsurekci Y, Tekcicek M, et al. Length of hospital stay an management of facial cellulitis of odontogenic origin in children. Pediatr Dent 2014; 36(1):e18-22.

5. Michael J, Hibbert S. Presentation and management of facial swellings of odontogenic origin in children. Eur Arch Paediatr Dent 2014; 15(4):259-68.

6. Lin Y, Lu P. Retrospective study of pediatric facial cellulitis of odontogenic origin. Pediatr Infect Dis J 2006; 25(4):339-42.

7. WangJ, Ahani A, Pogrel MA. A five-year retrospective study of odontogenic maxillofacial infections in a large urban public hospital. Int J Oral Maxillofac Surg 2005; 34(6):646-9.
8. García Villarmet C, De la Teja Ángeles E, Ceballos Hernández $\mathrm{H}$, et al. Infecciones faciales odontogénicas: Informe de un caso. Acta Pediatr Mex 2007; 28(3):95-100.

9. Unkel JH, McKibben DH, Feston SJ, et al. Comparision of odontogenic and nonodontogenic facial cellulitis in a pediatric hospital population. Pediatr Dent 1997;19(8):4769.

10. De la Teja AE, Escudero CA, Elías MG. Infecciones Odontogénicas. Acta Pediatr Mex 1999; 4(5):208-10.

11. Gutiérrez Pérez JL, Perea Pérez EJ, Romero Ruiz M, et al. Infecciones orofaciales de origen odontogénico. Med Oral Patol Oral Cir Bucal (Ed Impr) 2004; 9(4):280-7.

12. Acosta MG, Bolívar M, Nuñez N. Manejo de infecciones odontogénicas en niños. Revisión de la literatura. Rev AMOP 2017; 29(2):52-8.

13. Leitao A, Pedemonte T, Basili E. Microorganismos predominantes en abscesos odontologicos de adultos y niños. Rev Dent Chile 2004; 95(2):29-33.

14. Domínguez GuerraS, Machín HernándezA,Paredes Suárez $\mathrm{M}$, et al. Comportamiento de la celulitis cérvico-facial en una comunidad venezolana. Rev Ciencias Médicas 2012; 16(2):78-81.

15. Sánchez Saldaña L. Celulitis facial odontogénica en niños. Dermatol Peru 2012; 23(2):72.

16. Chura N. Celulitis cervicofacial de origen dentario. Rev Act Clin Med 2010; 1(3):40-5.

17. Salazar M. Infecciones osteoarticulares y de piel. In González SN, Torales TA, Gómez BD. Infectología clínica pediátrica. 7.ma ed. México: McGraw-Hill Interamericana; 2004.Pages 3-31.

18. Maestre JR. Infecciones bacterianas mixtas de la cavidad oral. Enferm Infecc Microbiol Clin 2002; 20(2):98-101.

19. De Vicente-Rodríguez JC. Celulitis maxilofaciales. Med Oral Patol Oral Cir Bucal 2004; (9 Suppl):S126-38.

20. Juncar M, Popa AR, Lung T, et al. Septic metástasis of supuration of odontogenic origin. Chirurgia (Burcur) 2011; 106(3):359-64.

21. Azenha MR, Homsi G, García IR Jr. Multiple brain abscess from dental origin: case report and literatura review. Oral Maxillofac Surg 2012; 16(4):393-97.

22. Navazo Eguía A, Clemente García A, García Vicario F, et al. Tromboflebitis del seno cavernoso. A propósito de un caso. Rev Soc Otorrinolaringol Castilla León Cantab La Rioja 2010; 1(16):1-8.

23. Pérez RA, Cueto RG, Escosura RG, et al. Mediastinitis necrosante descendente. Resultados del tratamiento médico-quirúrgico en 17 casos. Gac Med Mex 2003; 139(3):199-204.

24. Adelsdorfer Orellana C, Zuñiga González C, Díaz Díaz $\mathrm{P}$, et al. Manejo agresivo en mediastinitis necrotizante descendente. Rev Chil Cir 2005; 57(3):245-50.

25. Lizardo-Castro G, García D. ¿Qué debemos saber hoy en día de la fascitis necrotizante? A propósito de 2 casos. Rev Med Hondur 2011; 79(4):203-7.

26. Comité Nacional de Infectología. Infecciones de piel y partes blandas en pediatría: consenso sobre diagnóstico y tratamiento. Arch Argent Pediatr 2014; 112(1):96-102.

27. Rodríguez Lorenzo A, Midón Míguez J, Martelo Villar F. Síndrome del shock tóxico estreptocócico tras fascitis necrotizante por estreptococo pyogenes. Cir Plast Iberolatinoam 2007; 33(4):257-62.

28. La Orden Izquierdo E, RuizJiménez M, BlázquezFernández JA, et al. Revisión de celulitis periorbitaria y orbitaria. Experiencia de 15 años. Rev Pediatr Aten Primaria 2009; 11(44):597-606.

29. Jiménez Y, Bagán JV, Murillo J, et al. Infecciones Odo ntogénic as. Complicaciones. Manifestacio nes sistémicas. Med Oral Patol Oral Cir Bucal 2004; 9 Suppl:S139-47. 
30. Rodríguez Calzadilla M, García Vázquez M, Contreras Espuny M, et al. Enfisema periorbitario secundario a procedimiento dental: reporte de un caso revisión de la literatura. Rev Mex Oftalmol. 2017. [Accessed on: January $\left.12^{\text {th }}, 2018\right]$. Available at: https: / / www.sciencedirect.com / science/ article/ pii/S0187451917300859.

31. Medina Vega LD, Martín Pino J, Portal Fernández W, et al. Utilización de la moxibustion en el tratamiento de la celulitis facial odontogénica. Acta Odontol Venez 2006; 44(1):65-9.

32. Maestre Vera JR. Opciones terapéuticas en la infección de origen odontogénico. Med Oral Patol Oral Cir Bucal 2004; (9 Suppl):S19-31.

33. Dodson TB, Perrott DH, Kaban LB. Pediatric maxillofacial infections: A retrospective study of 113 patients. J Oral Maxillofac Surg 1989; 47(4):327-30.

34. Fine DH, Hammond BF, Loesche WJ. Clinical use of antibiotics in dental practice. Int J Antimicrob Agents 1998; 9(4):235-8.
35. Caviglia I, Techera A, García G. Terapias antimicrobianas en infecciones odontogénicas en niños y adolescentes. Revisión de la literatura y recomendaciones para la clínica. Odontoestomatología 2016; 18(27):46-9.

36. Bascones Martínez A, Aguirre Urízar JM, Bermejo Fenoll A, et al. Documento de consenso sobre el tratamiento antimicrobiano de las infecciones bacterianas odontogénicas. Med Oral Patol Oral Cir Bucal 2004; 9(5):36376.

37. Nishimura RA, Carabello BA, FaxonDP, et al. ACC/AHA 2008 guideline update on valvular heart disease: focused update on infective andocarditis: a report of the American Collegue of Cardiology / American Heart Association Task Force on Practice Guidelines endorsed by the Society of Cardiovascular Anesthesiologists, Society Cardiovascular Angiography and Interventions, and Society of Thoracic Surgeons. J Am Coll Cardiol 2008;52(8):676-85.

38. Costales González C, Zafra Anta MA, Alfaro Iznaola C, et al. Ingresos por celulitis facial odontogénica en un hospital de Madrid. Características clínicas y tratamiento. Act Pediatr Esp. 2015; 73(7):e158-64. 